
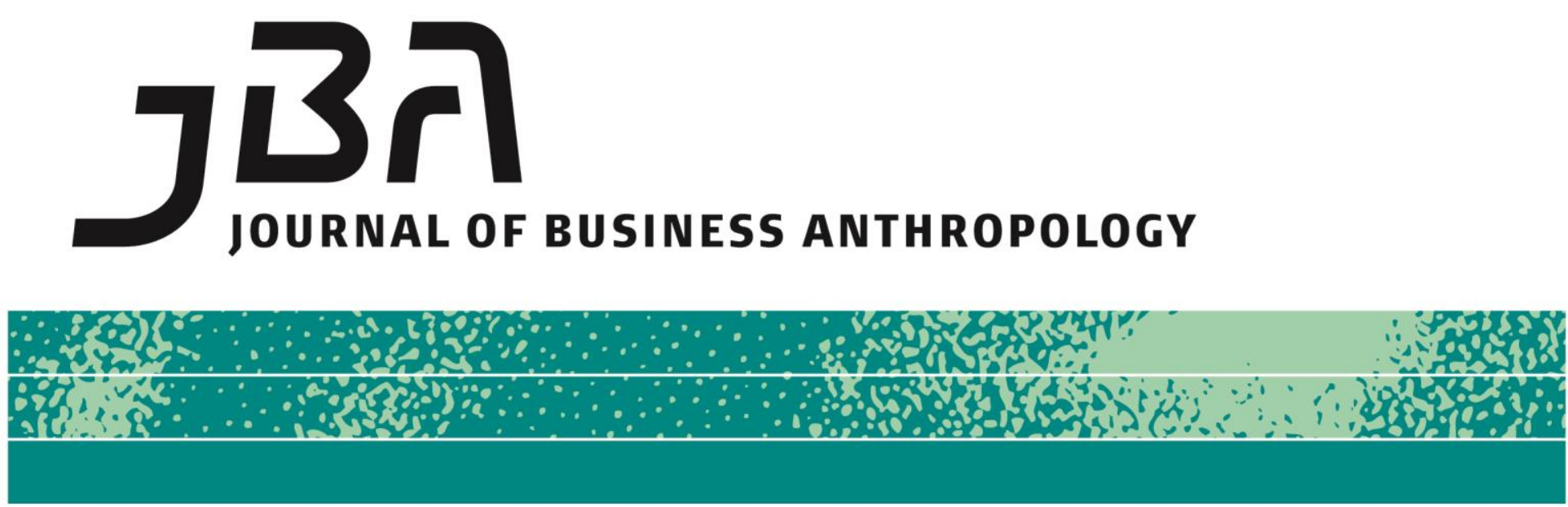

\title{
Taking the Notion of Family in Different Cultures Seriously: How Does the Cultural Context Affect Family Business Succession?
}

Hoi-yan Yau

\section{Introduction}

This paper aims to provide an anthropological perspective on the

Page 1 of 22 succession issues of family businesses, which have long been a major subject of inquiry within mainstream management studies of family businesses. According to the extant literature, more than $70 \%$ of companies worldwide are family-owned and/or -run (Dreux 1990: 225; Flören 1998). Nevertheless, less than half of these family businesses have managed to endure. In the US, for instance, less than 30 percent of family companies survive the transition to the second generation (Beckhard and Dyer 1983a; 1983b; Birley 1986), while only 15 percent make it to the third generation (Morris, Williams, Jeffery, and Avila 1997). The average life expectancy of family firms is estimated to be twenty-four years, which is also equivalent to the average tenure of their founders (Beckhard \& Dyer 1983a). As a result, succession issues of family businesses have become one of the most studied topics among management researchers as they seek to find out what factors prevent the successful transition of the family firm into the next generation.

While numerous scholars have offered important insights on 
succession issues in family businesses, the core issue of the succession of family businesses has largely been left untouched. One of the major problems of this literature is that it presents the family as an ahistorical or abstract ideal type, and thus it generally fails to delve into specific forms of the family in different cultures. Through an ethnographic example of a Japanese film studio, I will demonstrate that the succession of the family business in this instance was shaped by a culturally specific family logic. This suggests that different notions of family will give rise to different ways of dealing with the succession issue. In more concrete terms, I will show that the owner took great pains to ensure the continuity of the business, so much so that he was willing to pass the family business to his son-in-law when his own son proved to be unavailable. I contend that the fact that he was willing to do so has much to do with the traditional Japanese 'family' (known as ie) ethos that prioritizes the continuity of the family as an economic-cum-religious unit (or corporate-ie) rather than as a kinship unit (or kinship-ie), with the result that he felt obliged to bypass his son when the continuity of the family business was at risk. In other words, the family ethos has extended to the business world, so much so that the corporate-ie has taken on itself a deep logic and instinct for self-preservation. The Japanese example thus shows that 'family' business is not a restrictive starting point, a state in which businesses will eventually engulf family ethos and become more professional and less family-like. Rather, the Japanese corporate-ie absorbed the family ethos to become a stronger and more resilient corporate culture. In short, this paper seeks to contribute to 'reculturalize' the notion of family. In the first instance it will do so by briefly rehearsing the abstract portrayals of the family in the extant literature to see where the problems lie.

\section{How Have Succession Issues of Family Businesses Been Hitherto Interpreted?}

Due to space limitations, rather than offer a comprehensive review of the literature on the succession of the family business, this paper restricts itself to the research conducted by major mainstream management researchers published in the top-ranking American journals. ${ }^{1}$

This vast literature can be classified into six lines of academic inquiry. The first line of research conceptualizes succession as a 'process', rather than a once-and-for-all event in which the ownership of the company is passed from the predecessor to the successor (Longenecker and Schoen 1978; Churchill and Hatten 1987; Farquhar 1989; Friedman 1987). Longenecker and Schoen (1978: 4-5), for instance, have divided

\footnotetext{
${ }^{1}$ These include but are not limited to Family Business Review, Journal of Asian Family, Journal of Small Business Management, Entrepreneurs, Theory and Practice, and The Academy of Management Review.
} 
the succession process into seven stages, where the successor goes through a processual transformation ranging from the 'pre-business' stage, through the 'introductory' stage, the 'introductory-functional' stage, the 'advanced functional' stage, the 'early succession' stage to the 'mature succession' stage when the successor becomes the de facto leader of the organization.

Another conceptualization is to see succession as a social process in which the founder and the successor mutually adjust and adapt their roles. Specifically, this process focusses upon the transformation of the role of the founding owner from being 'the sole proprietor' to being 'the monarch', to being 'the supervisor and delegator', and finally to being 'the consultant' who leaves or retires from the organization (Handler 1994: 137). Correspondingly, the next generation of family members goes from having 'no role' or 'no defined role' in the business to being 'helpers', 'managers', and eventually 'leaders' and chief decision makers. In this approach, the focus is on succession in a family business that involves the adjustment of roles between the founder and the successor.

The second line of inquiry focuses on the psychodynamic aspects of the founder, and it specifically explores the kinds of events in childhood that may deter the founder from passing the ownership on to the successor (Venter et al 2005; Zellweger et al, 2010; Filser, Kraus, and Mark 2013). These studies show that childhood traumas such as 'the escape from poverty or insecurity', or 'the sudden death of their parents', or 'abandonment by their parents' have left the founders with a strong desire for power and achievement which, in turn, has made the family businesses take on a special role for their own psychological fulfilment. In such cases, the founders tend to be reluctant to pass the company over to a successor.

The third line of research draws our attention to the ambivalence of the chosen successor towards taking over the family business. For instance, Blotnick (1984) drew attention to the reluctance of secondgeneration owner-managers to join the family business. Likewise, Birley (1986) has examined how the second-generation of family business owners, who still were in college, were ambivalent towards the idea of 'returning' to the family firm after graduation. In the wake of the fact that members of the second-generation of owner managers were generally ambivalent towards inheriting the family business, a number of works (Iannariellis 1992; Handler 1989, 1992; Rogal 1989) have sought to find out which factors might enhance the willingness of members of the younger generation to take over the family business. It is contended that by paying more attention to these factors, this may help identify what might be done so that the second-generation might be more willing to take over the family business.

The fourth line of academic inquiry stresses the interaction 
between the founder and the successor. Management scientists of this line of inquiry, for instance, have adopted game theory to examine the strategic interaction between successors and founders. They have suggested that every player (i.e. all family members) be posited as risk neutral ${ }^{2}$ in order to maximize their expected payoffs so that families are motivated to retain the ownership of their businesses (Lee, Lim and Lim 2003: 658).

Some other management scientists analyse the interaction between the founder and the successor with social exchange theory. This presumes that the founder and the successor are rational agents attempting to maximize benefits and minimize costs in the succession process (Long and Chrisman 2014). Although these two theoretical frameworks are by no means the same, they both assume that players (i.e. founders and successors) are rational beings who are striving to maximise their respective gains.

The fifth line of academic inquiry highlights the fact that the process of succession involves two completely different systems: family and business (Neubauer 2003). As each of these systems has its own concerns and logic, the family business is seen as an arena where the two systems interact and hence a potential site where various conflicts may arise. While the founder might be well aware of the necessity and urgency to start succession planning, he, as the 'father' in the family, might often choose to refrain from doing it. Refrainment has been the most typical response to facing succession, especially when the older generation is already having to cope with their children leaving home and the empty nest, or the death or illness of their own parents (Lansberg 1988). In other words, the role of being a 'father' along with the wish to stay close to the children may prevent a founder from planning the succession of the family firm. Sometimes, the spouse may also attempt to prevent succession planning because the firm has played such an important role in her identity (Danco 1981; Rosenblatt, Anderson and Johnson 1985). It is easy to see that family members may interfere with succession planning of the family firm.

The sixth line of inquiry highlights the fact that succession not only depends upon the founder or the incumbent, but also such factors as the family, the organization itself, and the environment in which the organization is situated (Handler \& Kram 1988; and Bozer, Levin, and Santora 2017). Nonfamily stakeholders such as the management team are also an important factor in shaping the planning of succession (Bozer, Levin and Santora 2017). This line of inquiry aspires to identify all the dynamics involving the major players as well as the different contexts in

\footnotetext{
${ }^{2}$ It is assumed that they will maximize their expected payoffs and that families are motivated to retain the ownership of their businesses (Lee, Lim and Lim 2003: 658).
} 
the process of succession.

The major problem that runs through all this literature is its treatment of the family as an abstract and ahistorical concept and hence its failure to pay attention to the culturally specific form of the family in the succession process of the family business. Consider the literature of the first line of inquiry as an example. It reduces the complexity of the succession process to seven stages, in which the founder and successors mutually adjust and adapt. What is presented in this literature is a schematic representation of the stages of the succession of family businesses using terms such as 'monarch', 'manager', 'intern', and 'delegator' and so on which are much too abstract and indeterminate regarding the wide range of succession processes they are meant to cover. The power relations therein, which are obviously relevant to succession, are merely dissolved within the neat schematic description.

More importantly, the 'family' in the literature is always culturefree, as if a family had nothing to do with its wider cultural context. For example, we are not told whether the descent of the family at issue is patrilineal, matrilineal, or bilateral. As has been well documented, different lineages will give rise to different forms of the family. Descendants in Chinese families, as Wong argues in his paper of this special issue, follow the father's line and surname only, whereas the mother's line is simply rendered irrelevant. Only sons carry on the family line, whereas daughters cannot - for it is only sons who can obtain 'breath' ( $q$ i, the essence) from the father, and hence links to the supposed primogenitor through the chain of male ancestors, whereas the latter cannot. This gives males the prestige of permanent family membership while females are seen as only temporary members. Obviously, this understanding will have tremendous bearing on the succession issues of the family firm, especially on who is entitled to succeed the family firm. As daughters are temporary members, they are automatically excluded in the succession process from the very beginning.

The failure to pay attention to the culturally specific form of the family in turn gives rise to the abstract, undefined idea of 'the founder' and 'the successor.' As we have seen in the above literature, the childhood traumas of a founder might prevent him from passing the family firm onto the next generation. Similarly, the hesitation or unwillingness of the successor to take over the family business could substantially obstruct, delay, or even prevent the succession of the family firm. In both cases, the individual desires and preferences of the fathers and sons were seen as decisive, but the cultural factors involved in their decisions were not considered. Implied is the assumption of 'individual ownership'. Individual ownership means that a property (in this case, the family firm) is solely owned by a single person and that he has the absolute right regarding what/how to do with it, either selling it for money, giving it to a person he likes, or even disposing it for nothing. We learn from various 
ethnographic examples that individual ownership is not universal. As Wong quotes Chen in a recently published article (2017), neither fathers nor sons in the Chinese family have the absolute right in handling family properties as its transfer is governed by the principle of differentiating different fangs (the genealogical state of the son in the Chinese kinship system) within the jia-zu (the genealogical status of the father). The father is only entrusted to manage the property and allocate the income generated from the property. Hence, he is not allowed to distribute the property on his own will. Chen argues that the Western concept of individual ownership is simply absent in Chinese families. In fact, the family is the owner of its properties. Chinese 'fathers' or 'sons' cannot single-handedly determine the succession issues according to their own desires or preferences, as they after all function in terms of a code of conduct pertaining to the logics inherent in the kinship system.

Ignoring the cultural specificity of the family and its possible impact on the succession process of family firms puts the founders and the successors in a situation where they are seen as individuals free from cultural obligations. Game theory and social exchange theory see them as an 'Economic Man' in the succession process in which their sole goal is to maximize their personal utility or satisfaction. They are akin to what Sahlins quoted as the 'rational fool "Homo Economicus"'. Sahlins explains what they look like by quoting Hollis and Neil:

He is introduced furtively and piece by piece.... He lurks in the assumptions, leading an enlightened existence between input and output, stimulus and response. He is neither tall nor short, fat nor thin, married nor single. There is no telling whether he loves his dog, beats his wife or prefers pushpin to poetry [pushpin to Pushkin?]. We do not know what he wants. But we do know that whatever it is, he will maximize ruthlessly to get it (Quoted in Sahlins 2013: 164).

As I shall show in a case study of a Japanese family film studio, the father-owner in this case is notoriously possessive and infamous for his dictatorship style and emotional attachment to the family firm.

Nonetheless, he is at the same time under the influence of the imperative of Japanese family to ensure the continuity of the family firm. In the end, he was obliged to pass the firm to his son-in-law to ensure the continuity of the family business, when the possibility of passing it to his son was closed off. We can see that he did not just behave according to his desires and personalities, nor was he a fool 'Homo Economicus', aiming to maximize his well-being. Instead, he planned the succession of the family firm in terms of the logic of the Japanese ie (household), and hence was willing to bypass his son in favour of the son-in-law.

For this reason, succession issues of family businesses cannot be studied by merely singling out 'the founder' and 'the successor' and taking 
their roles as abstract or undefined, as if they behave the same way crossculturally. Thus, the cultural forms of family will serve to specify the succession issues, including the content, who are the potential candidates, as well as how the succession takes place.

\section{The Family in Japan}

The following discussion follows primarily on from Bachnik's (1983) award-winning paper on the Japanese ie. Bachnik identified two major characteristics of Japanese ie that are relevant to the current discussion.

First, Bachnik contends that 'position' is a more appropriate frame-of-reference than kinship in understanding the Japanese $i e$. 'Position' is the place a person occupies in the household, which 'defines the relation of each person to the household rather than to one another' (1983: 164). By making the distinction between 'successor' and 'nonsuccessor' dependent upon 'permanent' and 'temporary' positions within the household, Bachnik provides a frame of reference that is closely related to the succession issue. More importantly, there are only two permanent positions in the household in each generation, which, as she found in the data, is one of the most regular patterns about ie. One permanent position is the head of the household (kachō). It is occupied by a male, who is the official heir of the household and group property, the group manager, and the official social representative of the group (1983: 165). The other permanent position is held by the wife of the heir of the household.

Temporary members may or may not remain with the family during their lifetime. They usually do so only when they are able to move into a permanent position. Permanency is also associated with marriage; those in temporary positions cannot marry or remain in the family without moving into a permanent position. Permanent members remain in the family, not only during their own lifetime, but for a much longer period of time, as they become the ancestors of the family. The difference between temporary and permanent positions is evident even in the relationship to ancestors.

Seen thus, each generation of permanent members is distinguished by having different terms of reference and designation. Only one generation is acting head and spouse; the other generations are distinguished either by being 'retired' or 'incoming'. Children of the permanent members of each generation are temporary members. When succession of the Japanese ie occurs, the whole set of things including the headship of the ie, the ownership of the ie property, ie management, and the identity as the representative of the $i e$ will be passed onto the successor, whereas all the non-successors will be side-lined.

Secondly, the single most important imperative of the Japanese ie 
is the continuity of the family as an economic unit at the expense of the genealogical or blood extension. As Bachnik (1983: 160-1) notes perceptively, the Japanese $i e$ has been widely defined as both a kinship organisation and a corporate unit ${ }^{3}$ - and $i e$ as the corporate unit has two clearly-understood senses: that of a socioreligious group, which includes the $i e$ history and its ancestors, and that of the group enterprise, including the property and physical house. She points out that these two definitions of $i e$ are very different, involving as they do very different organisational criteria for recruitment. Hence they also have very different implications for how to understand succession. For instance, kinship succession in the $i e$ is defined by the relationship of 'father'/'son' and continuity of the kinship-ie requires the reproduction of its members over time. Continuity of the corporate-ie, by contrast, is defined by the reproduction of the corporate organisation over time, and the importance of a competent successor who will be able to maintain the business (Bachnik 1983: 1767). Obviously, the ie might not be organised by both kinds of succession, unless the son happens to be a competent successor who could ensure the reproduction of the corporate organisation. In other words, Japanese families will always be put at a crossroad if their sons are not as capable as they are expected to be. In analysing the household social organization in the prefecture of Nagano between 1967 and 1977, Bachnik contends that succession in the ie was organised by corporate rather than individual continuity, and the recruitment criteria of a successor was extremely flexible. She identified three strategies for recruiting a successor: (1) a male from the ingroup, a female from an outgroup; (2) a female from the ingroup, a male from an outgroup (such as an adopted son-in-law) and (3) a male and a female from an outgroup (such as an adopted married couple) (Bachnik 1984: 170). The first two strategies involved the recruitment of one outgroup member, whereas the third one required recruiting two outgroup members. These strategies have given tremendous flexibility to Japanese family heads in choosing their successors. The second and third strategies, for example, allow Japanese family heads to pass over their incapable, unsuitable or unhealthy sons in favour of adopted sons, adopted sons-in-law, or even an adopted married couple, if they think that doing so can ensure the continuity of the corporate-ie. Focussing upon the importance of 'positional' organization within the Japanese ie can help us better understand the practice of

\footnotetext{
${ }^{3}$ As Wong mentions in his paper in this issue, there has long been an academic debate with regard to the definition of Japanese $i e$, with some arguing that it is a kinship unit, while others contend that it is more an economic unit (Ariga 1943, Befu 1962, 1963; Brown 1966; Nakane 1967; Kitaoji 1971). In a more recent article, Hasegawa (1991) argues that Japanese ie is better conceived as a unit of a bundle of rights and duties, rather than either as a kinship group or an economic household. Nevertheless, his research after all attests to the significance attached to the continuity of the corporate-ie over kinship-ie as the family heads made concerted efforts to ensure the continuity of the family enterprise.
} 
passing over the son in the succession of a family business. As Bachnik notes:

Positional organisation means that ie succession is not contingent on the maintenance of any specific form for the organisation of its successors, and thus allows the widest possibilities for succession options; that the organisation should continue takes precedence over how it continues. Positions thus provide flexibility for ensuring succession in the $i e$, because they allow it to be organised pragmatically (Bachnik 1983: 167, emphasis added).

As I will show in a moment, the characteristics of Japanese ie will have tremendous bearing on the succession of Japanese family businesses. First, as in the case of Japanese $i e$, when a Japanese family business is passed onto the next generation, the whole set of rights including ownership and management of the company will be passed onto 'one single person', i.e., the successor. Non-successor(s) may or may not remain in the family business. If a possible successor has been passed over or chooses to remain in the family business, he will merely take a backseat position, as he fully understands that he has no right to engage, or intervene, in the business.

Secondly, the priority of the corporate continuity over genealogical continuity can also be observed in Japanese family businesses. If Japanese family business owners deem their natural sons to be unsuitable for taking over the family business, they regularly pass on the company to capable persons such as their adopted sons, adopted sons-in-law, and so on. ${ }^{4}$ Hence passing on the family business to genealogically un-related members is not only culturally grammatical in the context of Japan, but also economically rational, as the ultimate goal of the Japanese family is to ensure the survival of the family as an economic unit (family business).

In the following pages, I will look at the case study of how a Japanese film studio likewise bypassed the natural son in favour of an adopted son-in-law to sustain the family business. All the data in the paper is based on extensive ethnographic fieldwork that began in 2013. ${ }^{5}$ This fieldwork primarily focused on a film studio called Mutō Pictures, ${ }^{6}$ which is now the major film studio that still produces pink film on a regular basis. During my research, I not only interviewed people in the industry, including the president, the managing director and many staff

\footnotetext{
${ }^{4}$ Notable family business that have passed onto nonfamily members include Isetan, Honda and Kaijia Corporation.

${ }^{5}$ The whole fieldwork was co-conducted by Dr. Heung Wah Wong; yet for the sake of simplicity, I will use 'I' instead of 'we' (likewise me instead of us) throughout the paper.

${ }^{6}$ Mutō Pictures is a pseudonym to protect the identity of the studio.
} 
members of Mutō Pictures, directors, assistant directors, actors, actresses, scriptwriters, and so on, but I was also present in numerous shootings to understand the industry and the problems it faced.

\section{The Case of Mutō Pictures}

Founded by Mutō Kōhei in 1962, Mutō Pictures is one of the oldest film studios in modern Japan. In the late 1910s, while in his 20s, Mutō Kōhei was a benshi, a performer who provided live narration for silent films. His career in the film distribution business started in the 1920s, when he began to manage a theatre in Tokyo. Later, he worked at Nikkatsu Movies ${ }^{8}$ where he was involved in film production. After WWII, he became the president of Fuiji Film ${ }^{9}$ and simultaneously ran a real estate company (Murai 1989: 26-7). In 1955, he was enlisted into New Tōhō (Shintōhō),10 at a time when the studio was deeply in debt (Sharp 2014[2008]: 32). Under his leadership, the company's fortunes turned around. Later, the studio shifted to produce sexploitation movies commonly referred to as 'erotic grotesque (ero-guro)'. Nevertheless, since the late 1950s, Shintōhō again ran at a deficit, paving the way for its eventual bankruptcy in 1961.

In 1962, Mutō Kōhei founded Mutō Pictures by incorporating Shintōhō's production facilities into Fuji Film (Sharp 2014 [2008]: 46, Nikaido 2014: 16). In the same year, Mutō Pictures released its Flesh Market, directed by Sato Kobayashi and starring Katori Tamaki. This film, later considered a pioneer of pink cinema, was a commercial masterpiece, grossing over 30 million yen at the box office (Nikaido 2014: 15). Since then, Mutō Pictures began producing mainly low-budget erotic films. Meanwhile, a journalist coined the term 'pink film' to describe this emerging film genre, as pink has been traditionally used as a metaphor for sex. However, amid the prosperity of the pink film genre, the sudden death of Mutō Kōhei caused Mutō Pictures to confront their first succession problem.

\footnotetext{
${ }^{7}$ Mutō Kōhei, like the family business itself, is merely a pseudonym to protect the identity of our company source.

${ }^{8}$ Founded in 1912, Nikkatsu Corporation is one of the oldest film studios in Japan. In the 1970s, Nikkatsu launched a variant of pink film, known as Roman Porn, which brought Nikkatsu to the peak of their popularity. When the genre closed down in 1985, Nikkatsu still engaged in a number of film related businesses such as operation of the production studio, overseas film acquisition and distribution, a cable TV channel and so on.

${ }^{9}$ Founded in the 1950s, Fuji Eiga Co., Ltd was a Japanese film company. It was the predecessor of the current Mutō Pictures.

${ }^{10}$ Shintōhō Co. Ltd. was a Japanese film studio. It was one of the big six film studios (which also included Daiei, Nikkatsu, Shochiku, Toei Company, and Toho) during the golden era of Japanese cinema. It was founded by defectors from the original Toho company following a bitter strike in 1947.
} 


\section{The First Succession}

Before we proceed to examine the succession issues of Mutō Pictures, let me first introduce the Mutō's family and the constitution of the Board of Director (see Figures 1 and 2 which will be frequently returned to in the rest of the discussion). As we can see in the first and second generations of Mutō's family tree, Kōhei had a younger brother called Yūta. After Kōhei married, his wife gave birth to two sons, Takeshi and Ryō, and two daughters. Apart from his official wife, Kōhei had a lover with whom he had an illegitimate son. Kōhei was the founder and president of the company. Yūta, his younger brother, was appointed as the vice president in the 1960s (Figure 2).
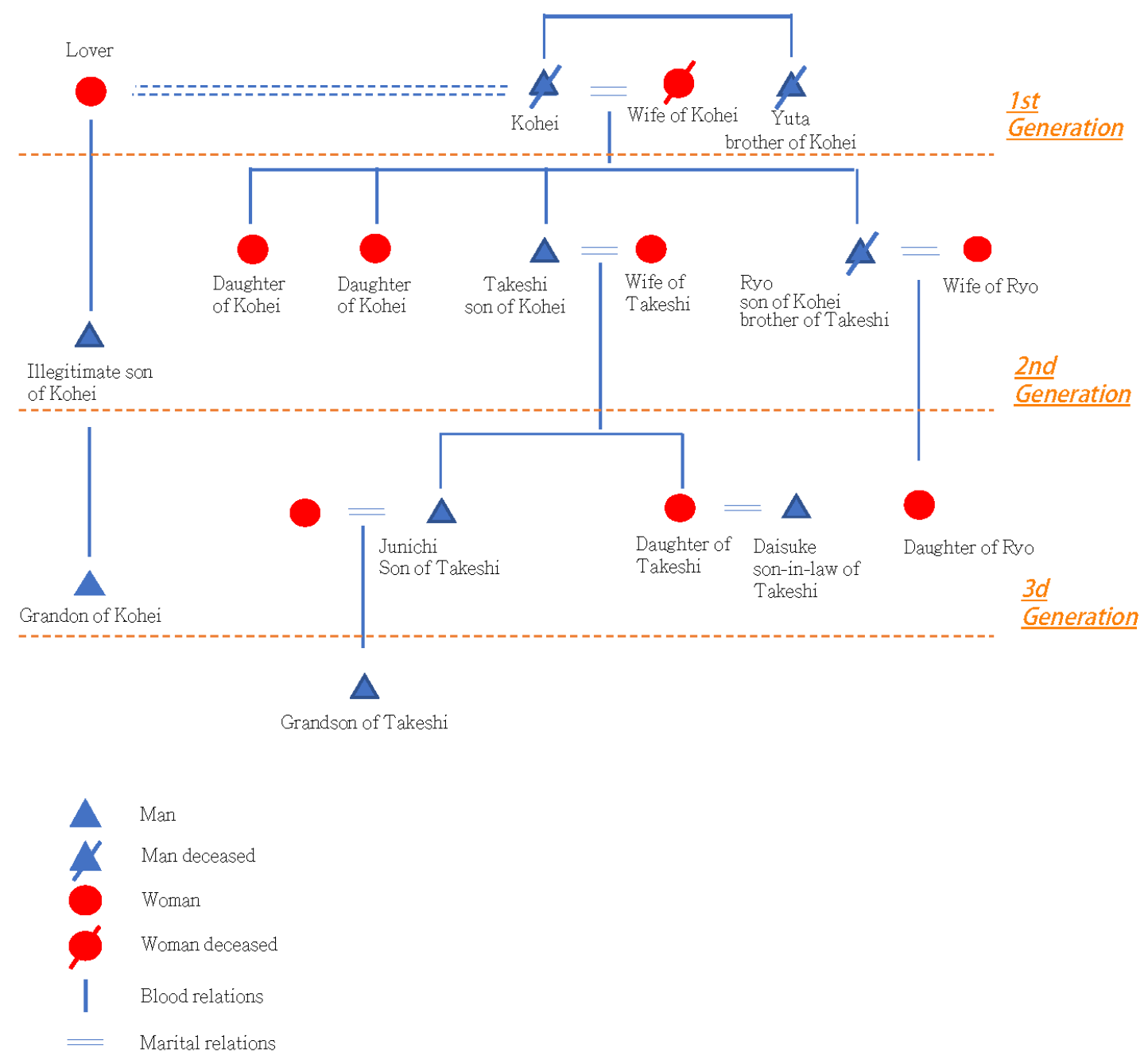

Figure 1. The Family Tree of Mutō's Family 

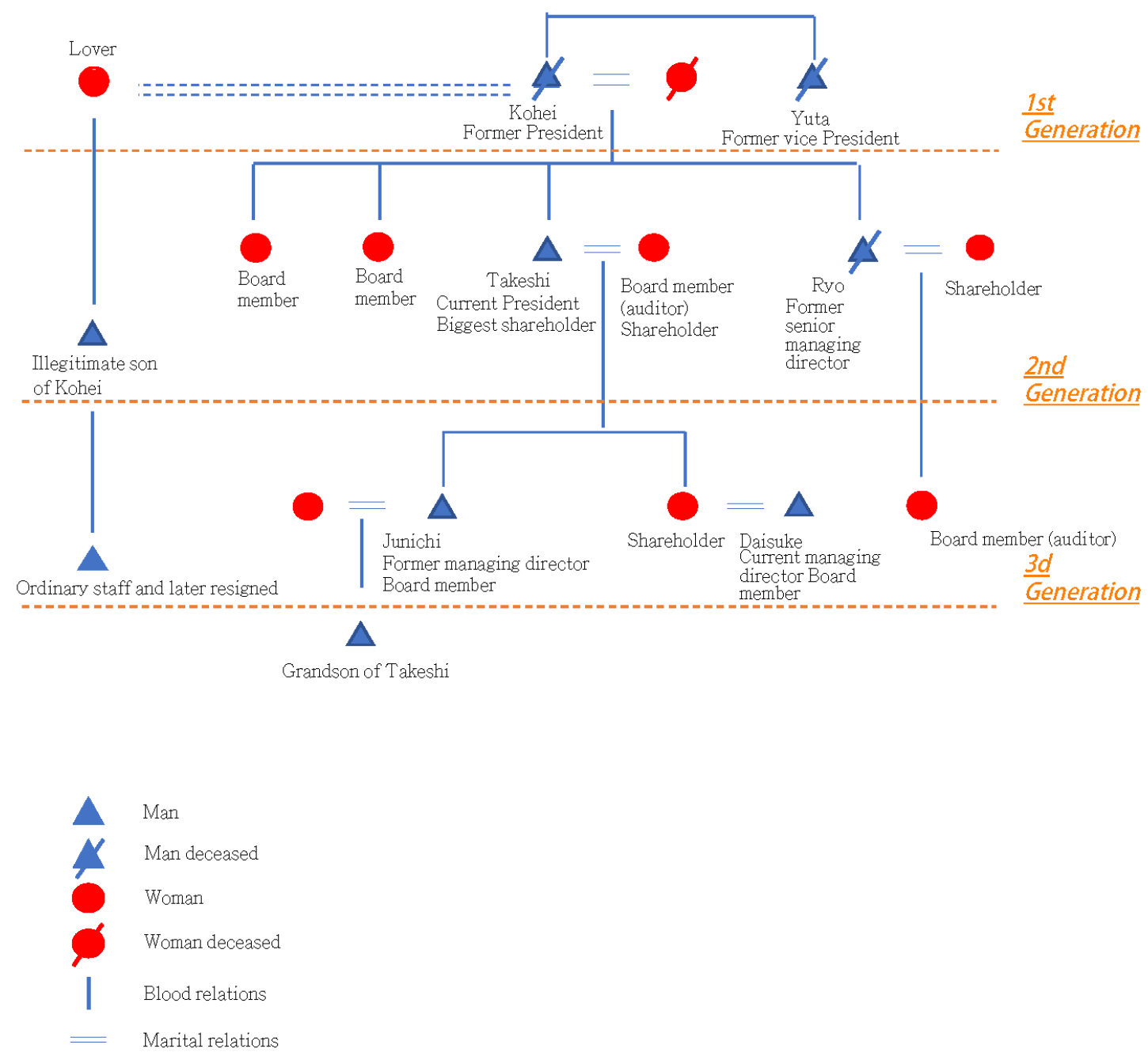

Figure 2. The Constitution of Board of Directors of Mutō Pictures

In 1978, Kōhei passed away due to pneumonia at the age of 79 . The next legitimate heir, had he been suitable, would have been his brother, the vice president, Yūta. But Yūta was a renowned singer and actor, and too preoccupied to lead the company. The focus then turned to Kōhei's two sons: Takeshi and Ryō. Eventually, the older son, Takeshi, who was considered more suitable than Ryō, inherited the company. In part this was because he was the oldest son, but it was also because he was more interested than his younger brother in running the family business. Takeshi thus became the second-generation successor of the company (see Figure 2)

Upon inheriting the company, Takeshi soon realised that some measures were needed to deal with the market decline of pink film caused by competition from the emergence of adult videos (AVs) in the early 1980s. Elsewhere (Wong and Yau 2014, 2018), we have provided a detailed introduction about AVs, here we just would like to point out that Japanese AVs are hardcore pornographic movies designed to be 
consumed in the comfort and privacy of one's living room. Not surprisingly, AVs quickly outsold pink film, because they offered privacy, hardcore sex, and a variety of sexual fantasies that the latter could not. By the late 1980s, adult videos had largely taken over the the pornography market, and making pink film was becoming less commercially viable. To rescue the family business, Takeshi further diversified the company. Thus from the 1980s, Mutō Pictures began to invest in sports facilities and real estate. By the 2010s, Mutō Pictures owned and operated three bowling alleys, a golf driving range, and a batting practice facility for baseball across Japan. Its real estate portfolio included restaurants, entertainment complexes, office buildings, apartment complexes, and parking facilities. Of its three business lines - pornography, sports, and property - only real estate were making money; sports only managed to break even, while its pink film business had been deteriorating since the 1980s. Takeshi proved to be an outstanding successor who had implemented measures to prevent the company from running at a loss.

The need for Takeshi to start planning for the succession of the company had become increasingly evident to him. First, due to his age, he had become aware of his physical limitations and thus the need to recruit a younger person to help him with various aspects of the family business. Secondly, as a member of the second generation, who had inherited the family business from the founder, Takeshi viewed his mission in life as ensuring that the company would be successfully passed onto the next generation. Third, the declining popularity of pink film and hence revenue from them was another factor that bothered Takeshi because if the pink film business continued to be in the red, the loss had to be covered by the revenues of other businesses. Thus, Takeshi was obliged to look for someone who could help revive and rejuvenate the pink film business.

His desire to sustain the pink film genre was also motivated by what may be a unique feature of Japanese corporate culture: viz., the emotional obligation by company owners to ensure the ongoing employment of all their employees. A Japanese company sees its employees as people with whom it forms a 'long term relationship' (nagai otsukiai), and to whom it is thus 'grateful and indebted' (osewa ni natta hito). The same is also true for Mutō Pictures. On a number of occasions, both Takeshi and staff members expressed to us their gratitude and indebtedness towards their workforce, including directors, assistant directors, actors, and actresses and so on, for the effort they made. When asked why they did not simply close down the film business and focus mainly on real estate, they unanimously replied that the company would strive to produce pink film until the last minute, for if they ceased to produce pink film, all the people who have hitherto relied on the company would instantly lose their jobs; and this is especially so, as Mūto Pictures is now the only studio that still produces the genre. Takeshi felt he owed it to his employees in pink film not to give up the genre or close down the 
film business. All these factors thus made the succession planning of the studio a burning issue for Takeshi.

\section{The Second Succession in Progress}

Takeshi has two children: a son, Junichi, and a daughter. Junichi joined the company as a board member when he graduated with a Master's degree in Fine Arts in his mid-20s. After a couple of years of onsite training, he was promoted to the position of 'managing director' (jömu). Takeshi had planned to pass the company onto Junichi. But things did not turn out as planned, and the relationship between the father and son turned sour before the succession had occurred. As Junichi became familiar with the operation of the company, perhaps it was no surprise that he would develop different attitudes and opinions on various company issues. Moreover, the father, who was still the de facto owner of the company, frequently intervened in the management and direction of the company. As documented by many other scholars on business succession (Kaye 1996; Danco 1980; Ketts de Bries 1985), it is not uncommon for the incumbent to feel attached to the company he has managed and reigned over for many years. Eventually, in 2012, and after a fierce fight with his father, Junichi quit the company.

From what we have learnt from our company source, although Junichi has remained a board member and still receives a monthly salary from the company (see Figure. 2), he has not only ceased performing any duties in the company, he has no contact with his father. In 2017 Takeshi undertook radiotherapy and electrotherapy for cancer. Although he survived, and despite his age and ongoing poor health, Junichi has still refused to see his father.

When Junichi decided to quit the company in 2012, Takeshi had already put his plan B into action. Although he has a daughter, his daughter had long since been settled in the US and had no intention of returning to Japan, even to inherit the family business. ${ }^{11}$ In view of this succession impasse, in 2013 Takeshi thus decided to pass on the business to her husband, and his son-in-law, Daisuke ${ }^{12}$ (see Figure. 1) .

Daisuke was born and raised in Japan. After graduating from a university in Tokyo, he started to work in one of the top advertising agencies in Tokyo. In his mid-30s, he made a bold decision to pursue his 'American' dream. Eventually, his English proficiency enabled him to be admitted to a Master's degree at a renowned university in the US. Upon graduation, he began to work in a number of entertainment related

\footnotetext{
${ }^{11}$ His wife had chosen to stay in the US, while Daisuke alone went back to Japan to take care of the family business.

${ }^{12}$ Again, it is a pseudonym to protect the identity of my source.
} 
businesses such as mobile/online games, advertising, consulting, singing and acting schools in the US. Before he came back to Japan, he was working in a company in Hollywood specializing in online/media games.

In many ways, even if not the first choice, Daisuke was a suitable heir of Mutō Pictures. For he had spent many years engaging in such entertainment fields as advertising, music, movies, and mobile games. $\mathrm{He}$ was also well-versed in English and had international exposure. Unlike a locally hired manager, he would certainly bring an international depth of experience to Mutō Pictures that had so far been focusing primarily on the domestic market. Thirdly and finally, Daisuke was very willing to return to Japan to take care of the family business, and, on Takeshi's death, eventually inherit it.

In April 2013, Daisuke officially became the managing director of Mutō Pictures, a position previously occupied by Junichi. Clearly, Takeshi considered the continuity and prosperity of the company far more important than the continuity of his own family line, so much so that he was willing to bypass his only son and give the family business to his sonin-law.

\section{Mutō Pictures Under the New Managing Director}

Takeshi's choice in passing the company onto Daisuke proved to be an appropriate one in sustaining the company. Just six months after Daisuke came to Mutō Movies in 2013, he made a bold decision to reshuffle the film business by integrating its different units into the Division of Film Business (eizō bu). Before the coming of Daisuke to Mutō Pictures, there were three divisions, namely the Business Division (jigyō bu), the Accounting Division (keiri bu) and the General Affairs Division (sōmu bu). The four film business-related departments including Production (seisaku), Distribution (haikyū), Marketing (senden), and Theatre Management ( $k \bar{g} g y \bar{o}$, the actual screening) were independently managed and located in two different offices (the Ginza Office and the Ueno Theatre Office). In Daisuke's view, the whole film business was too loosely organised. Communication and cooperation among the four departments was poor. Daisuke thus decided to merge the separated units under one single division (see Fig 3). Daisuke also relocated the Production Unit from the Ginza Office to the Ueno Theatre Office (see Fig 3). He thought it important for members of the Production Unit to communicate more frequently with the Ueno Theatre Management Unit, as the latter are in direct contact with their audience and hence have a better understanding of audience taste. Daisuke wanted to tailor their pink films more to the taste of their audience. 


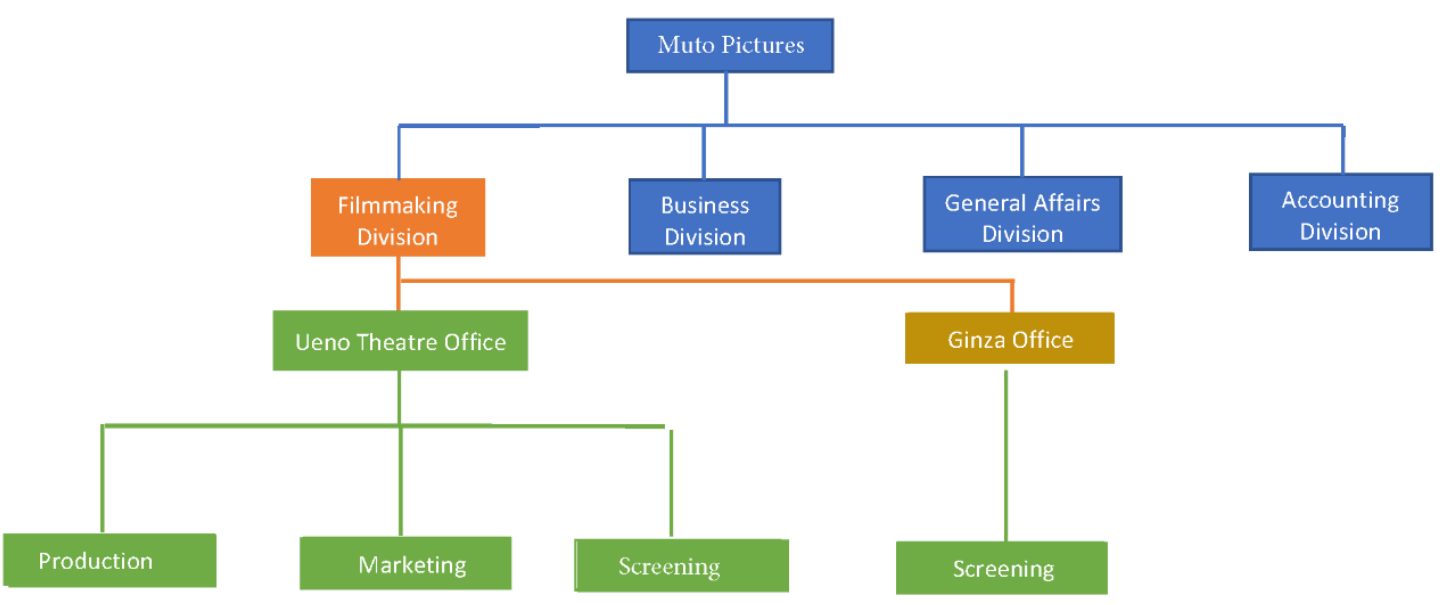

Figure 3. The new organizational structure of Mutō Pictures

After reshuffling the organization to facilitate the wider circulation and production of better-quality pink film, the next thing he did was to expand the viewership of pink film. To this end, he was seen first to expand the domestic market by facilitating the emergence of R-15 (restricted to people aged 15 or older) pink film. According to film regulation in Japan, because pink film involves sexually explicit material even though genitalia are airbrushed, and all sex scenes are simulated they have been classified as 'restricted to persons of 18 years and older' (R-18). This classification in turn made pink film only available in the 'adult theatres' (seijin eigakan), as regular theatres, especially chain theatre outlets, had long refused to screen pink film for fear that screening them would dissuade cinemagoers not interested in pornography from visiting their cinemas. To expand their viewership, Daisuke decided to start producing R-15 versions of pink film. The first R15 version of pink film was launched in 2014. This strategy proved to be very successful, as the viewership of pink film as well as theatre revenue generated from them increased. This was considered a milestone by the industry people as pink film could now reach a wider audience base, including women viewers.

To further expand the viewership of pink film, Daisuke also developed the idea of bringing pink film to the overseas market whilst promoting them under the new label, 'New Japanese Erotica'. This strategy had been facilitated by Daisuke's overseas experience and international exposure. Since 2014, Daisuke also participated in a number of international film festivals in Hong Kong, Korea, the US and Tokyo in order to attract overseas buyers. He and his staff also frequently visited buyers in foreign countries. The success of the strategy can be seen by the fact that by 2020 the market for pink film had expanded to include Hong Kong, Taiwan, Korea, the US, and a number of European countries. 


\section{Corporate-ie Over Kinship-ie}

Two observations can be made in view of the above succession processes. First, corporate-ie takes precedence over kinship-ie in the succession of the family business. If kinship-ie had been the major issue, then any of the three potential candidates, Yūta, Takeshi and Ryō would have been equally acceptable. Nevertheless, Kōhei excluded Yūta and Ryō in favour of Takeshi, whose character, as far as we learned from our company source, most closely resembled that of his father, in particular in being smart and decisive in the face of difficulties. In other words, Takeshi was chosen because of his suitability as the successor who could run the company far better than the other two; and Kōhei thereby prioritised the continuity of corporate-ie over that of kinship-ie.

The same is also true for the subsequent succession. Although, kinship is a factor and Takeshi originally planned to pass the family business onto his son, Junichi, when Takeshi thought Junichi ill-suited for the task, he summoned Daisuke, his son-in-law to come back from the USA to take over the family business.

Secondly, the succession of ownership and management of Mutō Pictures also followed the Japanese logic of the corporate ie. As mentioned above, when the Japanese $i e$ is passed onto the next generation, the whole bundle of rights including the headship, ie property and management, will be passed onto the successor, side-lining all the non-successors. Thus, when Mutō Pictures was passed from Kōhei onto Takeshi, both the ownership and management was passed onto Takeshi, and Takeshi's brother, Ryō was side-lined. As we can see from Figure 2, Takeshi is the biggest shareholder, while Ryō and his wife were only given a very tiny portion of the company's share - according to our inside source it was less than 3\% of the company's total shares (see Fig 2). After Ryō's death, his wife even agreed to sell her shares to Takeshi, upon the latter's request. We can see that Ryō's wife, as the widow of the nonsuccessor, did not hesitate to give up the ownership of Mutō Pictures, for she understood very well that she should better take a backseat in the family business, just as Japanese non-successors would do in the ie succession.

To be sure, Ryō served as the senior managing director (senmu) in the company before he died in 2005 (see Figure 2). Yet, as our inside source told us, his role was more or less ceremonial, and he was not regularly present in the office; nor did he actively engage in the management of the company. Upon his death, his only daughter was recruited into the company as the auditor (kansatsuyaku) of the company board (see Figure 2). But while Japanese commercial law requires the appointment of a statutory auditor to oversee the activities of the company, the position in Japanese corporate culture is merely ceremonial; statutory auditors are promoted from within the company 
and are therefore subordinates of the president. Very often, they are not even required to have any auditing experience. They are thus tasked with the impossible mission of acting as watchdogs of their superiors (Wong 1999: 39).

The same is also true for the remaining board members. As we can see in Figure 2, they include Takeshi's two sisters, his wife, his son, and Daisuke. As they are all appointed by Takeshi and hence his subordinates, again, their role is completely ceremonial. In other words, not only the ownership, but also the management of the company rests entirely with Takeshi. We can see that there is a strong parallel between Japanese ie and Japanese business practice as Takeshi is in full control of the company both in terms of ownership and management.

\section{Conclusion}

The idea of this paper is simple. The study of the succession issue in family businesses would not be complete without taking the culturally specific notion of 'family' seriously. Family is never an abstract or undefined concept but has culturally specific meaning and logic. This paper has shown that there is a dual concept to Japanese ie in business: it is simultaneously a kinship organisation and corporate unit, hence kinship-ie and corporate-ie. Yet these two characters are not equally important: the corporate-ie is always superior to the kinship-ie. Family heads were seen to frequently bypass their sons and incorporate nonfamily members to take over the corporate-ie. This pattern is shown clearly in this paper's ethnographic case study of Mutō Pictures. Kōhei was seen to rule out Yūta and Ryō in favour of Takeshi, because the latter was viewed as the most suitable candidate. Likewise, Takeshi was seen to finally bypass his son in favour of his son-in-law.

More importantly, the nature of succession of Mūto Pictures followed neatly the logic of Japanese ie, in that succession involves the passing on of a bundle of rights. Thus, the succession of Mūto Pictures also involved the transition of both ownership management from the former president, Kōhei, to Takeshi, where the non-successor (Ryō) was completely side-lined.

This case study demonstrates that the founder of Muto Pictures could never behave merely according to their personal desires or preference regarding the succession of family business; nor were they merely Homo Economicus striving to maximize utility in planning the succession. Instead, the content of succession (what items are to be transferred), the determination of eligible candidates, and how the succession is to proceed, are all specified by the logic of Japanese ie. Thus, this case study of Japan demonstrates how succession issues in family businesses are dependent on the family culture in which they operate. 


\section{References}

Ariga, K. 1943 Nihon kazōku seidō to kosaku seidō [Family system and tenant system in Japan]. Tokyo: Kawade Shobō

Bachnik, J. 1983 'Recruitment Strategies for Household Succession:

Rethinking Japanese Household Organisation.' Man, 18(1), new series, 160-182. https://doi.org/10.2307/2801769

Beckhard, R. and W.G. Dyer. 1983a 'Managing change in the family firm Issues and strategies.' Sloan Management Review 24: 59-65.

-------. 1983b 'Managing continuity in the family-owned business.'

Organizational Dynamics 12(1): 5-12. https://doi.org/10.1016/00902616(83)90022-0

Befu, H. 1962 'Corporate emphasis and patterns of descent in the Japanese family.' In R. J. Smith and R. K. Beardsley (eds.) Japanese culture: its development and characteristics. New York: Wenner-Gren Foundation for Anthropological Research.

Befu, H. 1963 'Patrilineal decent and personal kindred in Japan.' American Anthropologist 68: 1328-1340. https://doi.org/10.1525/aa.1963.65.6.02a00070

Birley, S. 'Succession in the family firm: the inheritor's view.' Journal of Small Business Management 24:36-43.

Blotnick, S. 'The case of the reluctant heirs.' Forbes, Jul, pp.134, 180.

Bozer, G., L. Levin, and J.C. Santora. 2017 'Succession in family business: multi-source perspectives.' Journal of Small Business and Enterprise Development 24(4): 753-774. https://doi.org/10.1108/ISBED-10-2016$\underline{0163}$

Brown, K. 1966 'Dōzoku and the ideology of decent in rural Japan.' American Anthropologist 68: 1129-1151. https://doi.org/10.1525/aa.1966.68.5.02a00020

Churchill, N.C. and K. J. Hatten. 1987 'Non-market-based transfers of wealth and power: a research framework for family businesses.' American Journal of Small Business 11(3): 51-64. https://doi.org/10.1177/104225878701100305

Danco, L.A. 1980 Insider the family business. Cleveland, Ohio: University Press.

Danco, K. 1981 From the other side of the bed: a woman looks at life in the family business. Cleveland: The University Press.

Davis, P.S. and P.D. Harveston. 1998 'The influence of family on the family business succession process: a multi-generational perceptive.'

Entrepreneurship Theory and Practice 22(3):31-53.

https://doi.org/10.1177/104225879802200302 
Dreux, D. 1990 'Financing family business: alternatives to selling out or going public.' Family Busines Review 3(3): 225-243. https://doi.org/10.1111/j.1741-6248.1990.00225.x

Farquhar, K.A. 1995 'Attributions and the Emergence of Leadership: Patterns in Employee Responses to Executive Succession.' In M.J. Martinko (ed.) Attribution Theory: an organization perspective, pp.149170. Boca Raton: Routledge. https://doi.org/10.4324/9781315137926-9

Flören, R. 1998 'The significance of family business in the Netherlands.' Family Business Review 9(2): 121-132. https://doi.org/10.1111/j.1741$\underline{6248.1998 .00121 . x}$

Freedman, S. 1987 'The succession process: theoretical considerations.' Paper presented at the annual meeting of the Academy of Management, New Orleans.

Filser, M., S. Kraus, and S. Mark. 2013. 'Psychological aspects of succession in family business management.' Management Research Review 36(3):

256-277. https://doi.org/10.1108/01409171311306409

Handler, W. C. 1990 'Succession in family firms: a mutual role adjustment between entrepreneur and next-generation family members.'

Entrepreneur, Theory and Practice 15(1): 37-51.

https://doi.org/10.1177/104225879001500105

Handler, W. C. 1992 'The succession experience of the next-generation.' Family Business Review 5(3): 283-307. https://doi.org/10.1111/j.1741$\underline{6248.1992 .00283 . x}$

Handler, W. C. 1994 'Succession in family business: a review of the research.' Family Business Review 7:133-157. https://doi.org/10.1111/j.1741-6248.1994.00133.x

Handler, W. C. and K. E. Kram. 1988 'Succession in family firms: the problem of resistance.' Family Business Review 1(4): 361-381. https://doi.org/10.1111/j.1741-6248.1988.00361.x

Hoy, F. and T.G. Verser. 1994 'Emerging Business, Emerging Field: entrepreneurship and the family film.' Entrepreneurship, Theory and Practice 19(1): 9-23. https://doi.org/10.1177/104225879401900101 Iannarelli, C.L. 1992. ' The socialization of leaders in family business: An exploratory study of gender.' Unpublished PhD dissertation, University of Pittsburgh.

Ketts, de Vries, M.F.R. '1985 'The dark side of entrepreneurship.' Harvard Business Review 63: 160-167.

Kitaōji, H. 1971 'The structure of the Japanese family.' American Anthropologist 73: 1036-1057. https://doi.org/10.1525/aa.1971.73.5.02a00050 Lansberg, I.S. 1988 'The succession conspiracy.' Family Business Review 
1(2): 119-143. https://doi.org/10.1111/j.1741-6248.1988.00119.x

Lee, K.S, G.H. Lim and W.S. Lim. 2003 'Family business succession: appropriation risk and choice of successor.' The Academy of Management Review 28(4): 657-666. https://doi.org/10.5465/amr.2003.10899446

Long, R. and J.J. Chrisman. 2014 'Management succession in family business.' In L. Melin, M. Nordqvist and P. Sharma (eds)The SAGE handbook of family business, pp.249-268, LA, London, New Delhi, Singapore and WC: Sage. https://doi.org/10.4135/9781446247556.n13 Longenecker, J.G. and J.E. Schoen. 1978. 'Management succession in the family business.' Journal of Small Business Management 16(3):1-6.

Murai, M. 1989 Bōku no pinku eigashi: hadaka no yumenendaiki. Tokyo: Daiwa Shobō.

Nakano, R. 1967 Kinship and economic organization in rural Japan. London: Athlone Press.

Neubauer, H. 2003 'The dynamics of succession in family businesses in Western European countries.' Family Business Review 16(4): 269-281. https://doi.org/10.1177/08944865030160040501

Nikaidō, T. 2014 pinku eigashi: yokubō no mukidashi. Tokyo: Sairyūsha. Rogal, K.H. 1989 'Obligation or Opportunity: how can could-be heirs assess their position?' Family Business Review 2(3): 237-255. https://doi.org/10.1111/j.1741-6248.1989.00237.x

Rosenblatt, P.C., de Mik, L. Anderson, R. M. and P.A. Johnson. 1985 The family in business: understanding and dealing with the challenges and entrepreneurial families face. San Francisco: Jossey-Bass.

Sahlins, M. 2013 What kinship is and what not is. Chicago and London: The University of Chicago Press. https://doi.org/10.7208/chicago/9780226925134.001.0001

Sharp, J. 2014[2008] Behind the Pink curtain: the complete history of Japanese sex cinema. Surrey: FAB Press Publication.

Wong, H.W. 1998 Japanese Bosses, Chinese Workers: power and control in a Hong Kong megastore. Surrey: Curzon.

Wong, H.W. 2017. 'What Is Chinese Kinship and What Is not.' In M. Han, H. Kawai, and H.W. Wong (eds) Family, ethnicity and state in Chinese culture under the impact of globalization,, pp.83-104. Encino, California: Bridge21. https://doi.org/10.4324/9781351012959-5

Wong, H.W. and H. Y. Yau. 2014 Japanese Adult Videos in Taiwan. Oxon and NY: Routledge. https://doi.org/10.4324/9781315818771

Wong, H.W. and H.Y. Yau. 2018 Japanese Adult Video Industry. Oxon and NY: Routledge. https://doi.org/10.4324/9780203762493

Venter, E., C. Boshoff and Maas, Gideon. 2005 'The Influence of Successor- 
Related Factors on the Succession Process in Small and Medium-Sized Family Businesses.' Family Business Review 18(4): 283-303. https://doi.org/10.1111/j.1741-6248.2005.00049.x

Zellweger, T.M., K.A. Eddleston, F.W. Kellermanns. 2010 'Exploring the concept of familiness: introducing family firm identity.' Journal of Family Business Strategy 1(1): 54-63. https://doi.org/10.1016/i.jfbs.2009.12.003

Hoi-yan Yau is a social anthropologist and senior lecturer at Lingnan University, Hong Kong. Her major research interests include the globalization of Japanese pop culture in East Asia, pornographic culture in Taiwan and Hong Kong, sexuality and gender, and Japanese colonialism in Taiwan. She has published a number of articles and books on these topics including but not limited to 'Cover Versions in Hong Kong and Japan: Reflections on Music Authenticity', (2012, The Journal of Comparative Asian Development), 'Sex as a Ritual:

Transforming Women's Sexual Being from "Human-like" to "Animallike" in Taiwan', (2011, East Asia: an international quarterly, coauthored with H.W. Wong), and Japanese Adult Video Industry (2018, Routledge, co-authored with H.W. Wong). 